\title{
How Corporate Social Responsibility Reporting Standards Address Stakeholder Needs in the Americas
}

\author{
Daniel Tschopp \\ Saint Leo University, 33701 State Road 52 \\ Saint Leo, FL USA 33574-6665
}

Tel: 1-352-588-8238Ｅ-mail: daniel.tschopp@saintleo.edu

Received: July 10, 2012 Accepted: July 24, 2012

doi:10.5296/emsd.v1i2.2081ＵRL: http://dx.doi.org/10.5296/emsd.v1i2.2081

\begin{abstract}
The current stage of Corporate Social Responsibility (CSR) reporting is defined by multi-stakeholder initiatives. An increasing number of stakeholder groups is putting pressure on corporations to act responsibly. More CSR reporting standards are being developed to address these needs. As the level of CSR reporting increases, it is important to consider if and how these CSR reporting standards are adequately addressing stakeholders' needs.

To accomplish this goal, the first step was to identify stakeholders' needs. Interviews with trade representatives from the thirty-five countries in North and South America were used to compile a list of stakeholders' needs in the region. Trade representatives were used because of their position in dealing with a variety of stakeholder groups that have various social and environmental agenda. Once stakeholders' needs were identified, then three of the most widely used CSR reporting standards were evaluated to determine the adequacy of coverage they provided.

The analysis in this article details how the different reporting standards met the stakeholder needs in the different regions of the Americas. The results of this article provided additional evidence that the Global Reporting Initiative's (GRI) G3 standards result in the most thorough coverage. However, even these standards failed to adequately report on some of the most controversial stakeholder needs in the region, such as job creation, competition, and employment. Therefore, some stakeholder needs are not being satisfied by the information in CSR reports as key issues are still not being adequately reported if companies are following these standards.
\end{abstract}

Keywords: Corporate Social Responsibility Reporting, Stakeholders, Social and Environmental Accounting, Global Reporting Initiative, Account Ability, Communication on 
Progress

\section{Introduction}

Early Corporate Social Responsibility (CSR) reports were marked by "green wash” reports and eco-marketing campaigns used to sway public opinion. This represented the first phase of CSR reports. However, in the late 1980s the impact of corporations was being viewed with greater concern and the term "stakeholder" was introduced leading to the leading to a second phase of CSR reports (Marlin and Marlin, 2003). This led to the current stage of CSR reporting involving a multi-stakeholder approach (Marlin and Marlin, 2003). This third stage involves investors and environmentalists who rely on CSR reports for different yet complimentary reasons, and the reporting and assurance organizations that bring the needed credibility to CSR reports. One of the main reasons the CSR movement came back in the 1990s was the increase in socially responsible investors. Stakeholders with social and environmental concerns now had a market based mechanism to influence corporate decision making. Investors used this leverage to demand more accountability from the companies they invested in. Stakeholders are using CSR reports as a tool to measure the performance of their own specific causes and impact on corporations.

The goal of this paper is to determine if stakeholder needs are currently being met by existing CSR reporting standards. This will be accomplished by focusing on the needs of stakeholders in the thirty-five countries in North and South America. To accomplish this, the stakeholders' needs in the Americas are identified through interviews with trade representatives and supporting literature. Trade representatives were selected because they often serve the interests of a variety of stakeholders; government, labor, environmental groups, corporations, small businesses, citizens, etc. Since they have to be cognizant of stakeholders' needs in their country they were selected as an informed group to provide reliable information.

Once stakeholder needs are identified, the next step includes an analysis of three CSR reporting standards to determine which one best address stakeholders' needs in the region. To accomplish this, the content, requirements, and guidelines of the most common CSR reporting standards are evaluated to determine the level they address the various needs of stakeholders in the region. If CSR reporting is to be used as a market-based instrument that addresses social and environmental issues, it is important that CSR reporting standards yield reports containing useful information for decision makers.

\section{Identifying Stakeholder Needs in the Americas}

The Americas was selected for this research because the thirty-five countries that make up this region provide a useful case study. The region is comprised of countries with a variety of characteristics for comparison and analysis. The countries that make up the region include least-developed countries, developing countries, and developed countries.

The level of CSR reporting is significant in developed countries and is on the rise in many developing countries in the region. Of the top 100 companies in a country, 82 issued a CSR report in the United States in 2011 (74 in 2008) and 79 in Canada in 2011 (62 in 2008) (KPMG, 2008; KPMG, 2011).There are several factors to explain why the level of CSR 
reporting in some developing Latin American (LA) countries has not been as abundant, including the lack of disclosure regulation, limited non-regulatory pressure, and a confidentiality culture in the region (Araya, 2006). However, some developing countries have significant levels of reporting including 88 of the top 100 Brazilian companies (78 in 2008) and 66 of the top 100 Mexican companies in 2011 (17 in 2008) (KPMG, 2008; KPMG, 2011). The level of reporting in many other LA countries is not as significant. However, some view CSR reporting as a means to improving the social and environmental conditions in developing countries. However, to properly work as a market based mechanism to accomplish this, CSR reports must yield decision useful information.

The goal of this research is to determine if these CSR reporting standards are providing stakeholders with useful information. Are the guidelines and reporting requirements meeting the stakeholders' needs? To answer this, the first step is to identify stakeholder needs. As previously explained, trade representatives will be used to accomplish this. Trade representatives represent the concerns of a variety of stakeholder groups on numerous issues. Therefore, a trade representative from each of the American countries was contacted for an interview.

\subsection{Interviews - Trade Representatives}

To obtain the interviews with trade representatives, the country's embassy in the United States was contacted. The embassy provided contact information to the appropriate department, either within the embassy if they had a trade department or in their home country, usually within the Ministry of Finance, Ministry of Commerce, Ministry of Economics, or Ministry of Foreign Affairs. There were various reasons some countries chose not to participate. Some did not have the time; some did not feel comfortable with the topic, and others just said no. Most of the interviews were with high ranking trade representatives who were directly involved in the negotiating process, including many that were directly involved in the negotiation of social and environmental issues. However, the interviews with the Dominican Republic and Guatemala were conducted with representatives from non-governmental trade promotion agencies. While they were not directly involved in negotiations, they had an advisement role and were recommended by government officials. In total twenty-five interviews were obtained from the thirty-five countries in the region. Table 1 provides a list of the trade representatives interviewed and their official position within each country.

Table 1. Interviews with Trade Representatives

\begin{tabular}{|l|l|l|}
\hline Country & $\begin{array}{l}\text { Trade } \\
\text { Representatives }\end{array}$ & Official position \\
\hline Antigua \& Barbuda & Dia Christian & Foreign Service Officer \\
\hline Argentina & Roberto Salafia & $\begin{array}{l}\text { Head of the Economic and Commercial Section through } \\
\text { the U.S. embassy }\end{array}$ \\
\hline Bahamas & Simon Wilson & Director of Economic Planning in the Ministry of Finance \\
\hline Barbados & Donna Forde & Trade Counselor \\
\hline Belize & Richard Reid & $\begin{array}{l}\text { Senior Trade Economist } \\
\text { Trade Policy Unit Directorate General for }\end{array}$ \\
\hline
\end{tabular}




\begin{tabular}{|c|c|c|}
\hline & & Foreign Trade \\
\hline Bolivia & Erika Duenas & Economic and Trade Counselor \\
\hline Brazil & Declined & \\
\hline Canada & Vern MacKay & $\begin{array}{l}\text { Deputy Director } \\
\text { Investment Trade Policy Division } \\
\text { (Department of Foreign Affairs and International Trade) }\end{array}$ \\
\hline Chile & Pablo Lazo & $\begin{array}{l}\text { Advisor to the General Director of Economic International } \\
\text { Relations of the Ministry of Foreign Affairs }\end{array}$ \\
\hline Colombia & Declined & \\
\hline Costa Rica & Esteban Aguero & Director of International Trade Negotiations \\
\hline Cuba & Declined & \\
\hline Dominica & Declined & \\
\hline $\begin{array}{l}\text { Dominican } \\
\text { Republic }\end{array}$ & Franklin Lithgow & Investment Promotion and Special Project Director \\
\hline Ecuador & Declined & \\
\hline El Salvador & $\begin{array}{l}\text { Yolanda De } \\
\text { Gavidia } \\
\text { Ernesto Samayoa }\end{array}$ & $\begin{array}{l}\text { Minister of Economy } \\
\text { Minister of Economy's Advisor }\end{array}$ \\
\hline Grenada & Junior Mahon & Trade Officer \\
\hline Guatemala & $\begin{array}{l}\text { Guillermo } \\
\text { Eduardo } \\
\text { Monroy } \\
\text { Estrada }\end{array}$ & $\begin{array}{l}\text { Executive Director } \\
\text { Centrarse }\end{array}$ \\
\hline Guyana & $\begin{array}{l}\text { Neville } \\
\text { Totaram }\end{array}$ & $\begin{array}{l}\text { Coordinator Ministry of Foreign Affairs FTAA } \\
\text { Vice-Minister }\end{array}$ \\
\hline Haiti & Declined & \\
\hline Honduras & Allan ElvirZelaya & Commercial Attache \\
\hline Jamaica & Alison E. Roofe & $\begin{array}{l}\text { Deputy Director } \\
\text { Foreign Trade Dept. } \\
\text { Ministry of Foreign Affairs \& Foreign Trade }\end{array}$ \\
\hline Mexico & $\begin{array}{l}\text { Trade } \\
\text { Representative }\end{array}$ & Trade Representative \\
\hline Nicaragua & Declined & \\
\hline Panama & Marleni Paulo & $\begin{array}{l}\text { Legal Advisor of the Negotiation Commission of the } \\
\text { Ministry of Commerce and Industry for the Free Trade } \\
\text { Agreements }\end{array}$ \\
\hline Paraguay & Declined & \\
\hline Peru & Declined & \\
\hline $\begin{array}{l}\text { Saint Kitts and } \\
\text { Nevis }\end{array}$ & Sam Berridge & Trade Policy Advisor \\
\hline Saint Lucia & $\begin{array}{l}\text { Mc. Donald } \\
\text { Dixon }\end{array}$ & $\begin{array}{l}\text { Trade Advisor } \\
\text { Ministry of Trade and Commerce }\end{array}$ \\
\hline
\end{tabular}




\begin{tabular}{|c|c|c|}
\hline $\begin{array}{l}\text { Saint Vincent and } \\
\text { the Grenadines }\end{array}$ & Clarence Henry & Director of Trade \\
\hline Suriname & Mauro Tuur & Permanent Secretary of the Ministry of Trade and Industry \\
\hline $\begin{array}{l}\text { Trinidad and } \\
\text { Tobago }\end{array}$ & Declined & \\
\hline United States & $\begin{array}{l}\text { Trade } \\
\text { Representative }\end{array}$ & Trade Representative \\
\hline Uruguay & Alberto Fajardo & Director of Mercosur External Trade Negotiations \\
\hline Venezuela & $\begin{array}{l}\text { Martin } \\
\text { Austermuhle }\end{array}$ & $\begin{array}{l}\text { Political Analyst } \\
\text { Political and Economic Department of Venezuelan } \\
\text { Embassy }\end{array}$ \\
\hline
\end{tabular}

Interviews were mostly telephone interviews lasting approximately thirty minutes. However, the interviews with representatives from Canada, Costa Rica and the Dominican Republic were fact-to-face interviews in their respective countries. These interviews were selected for face-to-face interviews because it was deemed important to travel to each of the following regions to experience the culture first hand; North America, Central America, South America and the Caribbean. Unfortunately, the interview with a trade representative from Brazil was canceled.

The goal of the interviews was to identify the specific social and environmental concerns of the different stakeholder groups in their country based on their engagement with these various groups. These concerns and issues would then be mapped to three different CSR reporting standards to determine if and how they were being addressed.

The results of these interviews are divided into the following regions: Non-Latin American countries (U.S., Canada), large LA countries (Brazil, Mexico, Argentina, Venezuela, Colombia, Chile, and Peru), and small LA and Caribbean countries (the remaining twenty six Caribbean, Central American and small South American countries). These regions were selected based on Gross Domestic Product (GDP), cultural, and economic similarities. The U.S. and Canada are the only two developed countries in the region and had the highest GDP among amongst the countries in current prices (IMF, 2012). They also have similar cultural, economic and political systems. The remaining countries were divided between large and small Latin American and Caribbean countries using GDP of $\$ 100$ billion as the cutoff (IMF, 2012). This grouping also aligns countries that are more culturally similar. Stakeholder concerns of the different regions were then identified using the responses obtained from interviews with trade representatives as support. This is useful because most of the trade representatives are in direct contact with the different stakeholder groups during trade negotiations and can serve as a reliable source to voice the important issues facing numerous parties. Therefore, the trade representatives were able to express the different concerns facing their government and a variety of different stakeholders in their respective countries. Figure 1 provides a summary of the interview question "What are the main social and environmental concerns of stakeholders in your country (citizens, investors, corporations, labor, and local communities)?” 


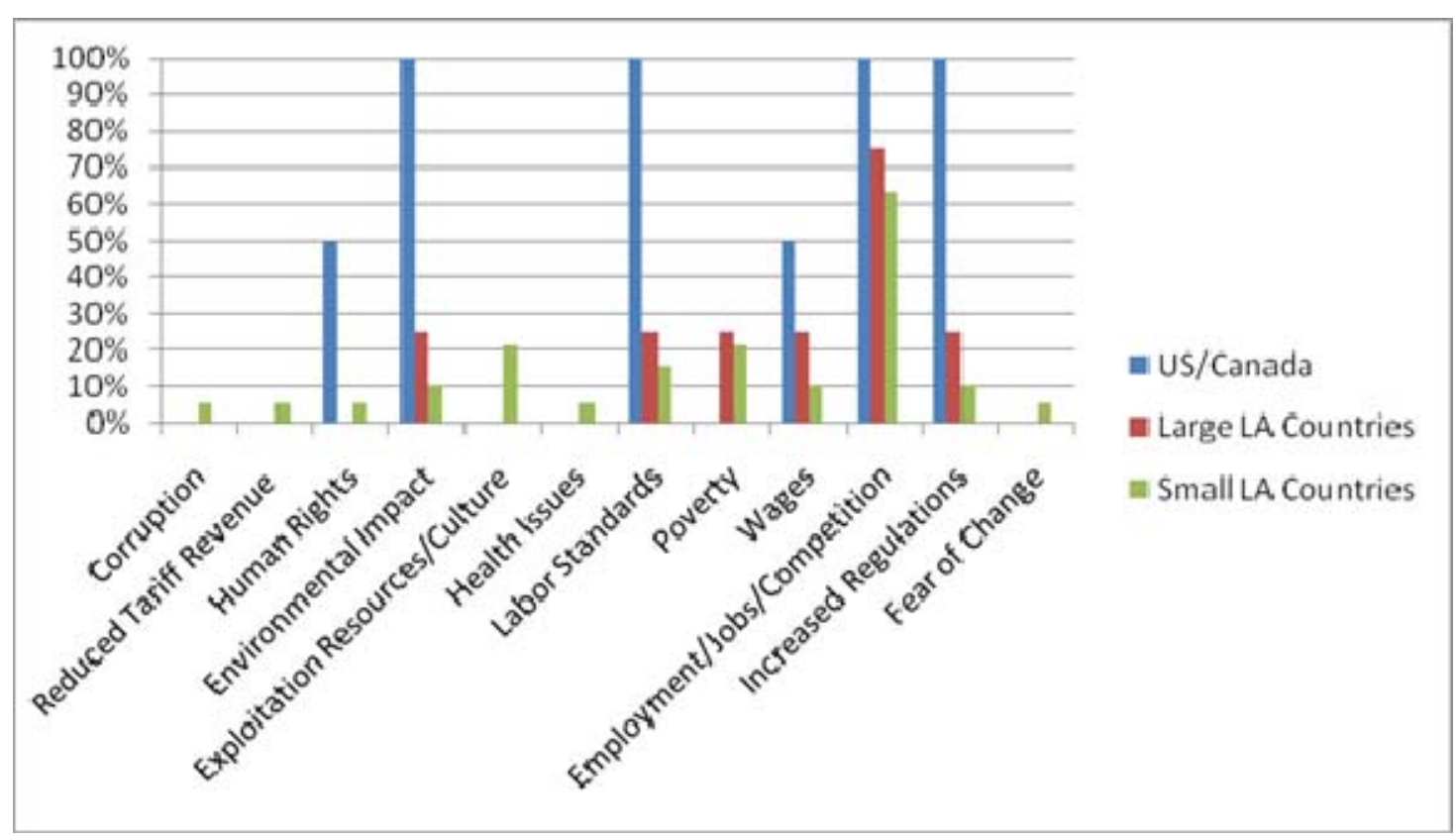

Figure 1. Trade Representative Responses to the question:

"What are the main social and environmental concerns of stakeholders in your country (citizens, investors, corporations, labor, and local communities)?”

The interviews with trade representatives from the U.S. and Canada resulted in consistent responses between both parties. The trade representatives were asked to identify the primary social and environmental concerns of the different stakeholder groups in their country. The U.S. and Canadian representatives both listed the following primary concerns of their stakeholders: environmental impact, labor standards, impact on employment, and the fear of increased regulations. In addition, human rights and wages were also mentioned by one of the representatives. Vern MacKay, the Deputy Director of the Investment Trade Policy Division in Canada believed that the concerns of corporations are more market-driven in the U.S. and Canada. He said that "North American companies are more sensitive to the consequences of being seen a poor performer" on social and environmental issues. Consumer and investor pressures are stronger in the U.S. and Canada, as opposed to LA countries where community and supply chain based pressures play a relatively larger role.

Some stakeholders' needs were weighted differently in LA than they were in the developed countries. Roberto Salafia, the Head of the Economic and Commercial Section of Argentina's embassy in the U.S., explained how his country's citizens are more concerned about poverty and improved economic conditions than environmental issues. He believes they are not as concerned about environmental needs, which they see more as a governance duty, providing the polluted rivers and streams in Buenos Aires as an example. The percentage of trade representatives interviewed citing environmental concerns decreased from $100 \%$ of Non-Latin American countries, to 25\% of large LA countries, to $11 \%$ of small LA countries. 
While there are many common concerns among the various stakeholders of the seven large LA countries, there are also some unique concerns specific to the different nations. For example, there are violence and political unrest in Colombia. There are illegal immigration issues in Mexico, both with Central America in the south and the U.S. in the north. Venezuela, because of their strong oil industry and leftist government, does not have the same concerns that others do. Martin Austermuhle, a Political Analyst at the Venezuelan embassy in the U.S. does not believe there is the same fear over the possible loss of jobs in his country as there is in other LA countries. He believes that because Venezuela's economy is so dependent on oil production, the social and environmental concerns would not be so dramatic in his country compared to those countries more reliant on agriculture.

Similar to the two other regions previously discussed, the primary stakeholder concerns in small LA countries appear to be job-related and their ability to compete. Many of the stakeholder concerns in the small LA countries have more to do, either directly or indirectly, with the basic economic conditions on the ground. Another concern faced in many LA countries has to do with the impact on their culture. This can include the fear of being "Americanized" or the exploitation of their natural resources by more developed countries. There are very diverse environments in this region and concern that their natural resources are used in their best interest, while at the same time preserving their own culture. This includes the complex relationship between intellectual property rights and biological diversity, for example, when large pharmaceutical companies use native ingredients in their products. There are also important concerns raised by indigenous communities, including migration issues, oppression, and civil rights.

In addition to the interviews, stakeholder concerns are identified via a review of timely journal articles and news sources. The news sources included the Latin Business Chronicle and Zona Latina. All of this combined allows for stakeholders' needs to be prioritized by region.

Social, labor, and environmental issues have become increasingly important during the presidential campaign in the U.S. The social concerns of developed countries tend to focus on the lower labor standards in developing countries. Humanitarian organizations are concerned about exploited workers and sub-par working conditions, while labor organizations in developed countries are concerned with union rights, outsourcing, and lower labor standards in developing countries that represent an unfair playing field resulting in job losses and lower wages. The current Presidential campaign in the U.S. brought up corporate accountability on issues relating to income distribution, healthcare, and job creation.

Environmental concerns also tend to differ between regions. U.S. and Canadian companies usually operate under more stringent environmental standards and regulations compared to other countries in the region. Their Governments have more resources to enforce regulations and their economies are strong enough to handle any additional costs. Acceptable levels of pollution and environmental degradation are usually lower in developed countries.

Stakeholder groups in large LA countries have some of the same concerns as stakeholders in the U.S. and Canada. They worry how the increased competition will affect their domestic 
industries. They worry that lower labor standards in neighboring, less developed countries will cost them jobs and lower their wages. Countries like Brazil and Venezuela are having power struggles with the United States over certain trade issues.

Stakeholder groups in large LA countries also share some of the same social and environmental concerns as their smaller LA neighbors in the region. As developing countries, they still face issues of poverty, pollution, and corruption that are at a much higher concern level than in developed countries. For example, in Brazil, $57 \%$ of cities have open garbage dumps and in Peru there are no sanitary landfills outside of the capital city of Lima (Borregaard, 2003). The LA region is also known as having the largest income disparities between its rich and poor (Sanchez, 2005). Table 2 provides a list of key social and environmental problems facing the entire LA region. This list was compiled by Nicole Borregaard as part of the research project "Southern Agenda on Trade and Environment" (2003). CSR reporting in much of LA is in its infancy. Araya identifies several factors to explain why CSR reporting in this region represents the lowest percentage (anywhere from 4-6\% of companies issue a CSR report) of any region in the world (2006). The environmental movement that started in Europe and that is gaining strength in the U.S. and Canada has not made a significant impacton all the LA or Caribbean countries yet. Their sustainability initiatives tend to focus more on eliminating poverty, creating jobs, and establishing an institutional framework to promote responsible business behavior as opposed to more market-based initiatives such as CSR reporting (Vives and Peinado-Vara, 2004). Vives and Peinado-Vara identify the elimination of poverty as the primary reason CSR initiatives are adopted in LA (2004). Reports give companies a way to be recognized for their humanitarian efforts and charitable giving.

Table 2. Social and environmental problems facing Latin America that are impacted by free trade

\begin{tabular}{|l|l|}
\hline \multicolumn{1}{|c|}{$\begin{array}{c}\text { Main regional environmental } \\
\text { problems }\end{array}$} & \multicolumn{1}{c|}{ Main regional social problems } \\
\hline $\begin{array}{l}\text { An accelerating overexploitation of } \\
\text { land and marine resources }\end{array}$ & $\begin{array}{l}\text { The integration of indigenous people is an } \\
\text { important socio-cultural aspect that has been } \\
\text { confronted in very different ways in the countries } \\
\text { of the region, and that has led to significant } \\
\text { conflicts throughout the last decade }\end{array}$ \\
\hline Nutrient depletion and soil erosion & $\begin{array}{l}\text { Demographic trends show that there is an } \\
\text { important change with regard to family } \\
\text { structures. }\end{array}$ \\
\hline $\begin{array}{l}\text { Overgrazing and subsequent } \\
\text { desertification }\end{array}$ & $\begin{array}{l}\text { The quality of work has decreased over the } \\
\text { decade of the 1990s, as shown for example by } \\
\text { the relative increase in employment in } \\
\text { low-productivity sectors. }\end{array}$ \\
\hline Continuing deforestation & $\begin{array}{l}\text { Drug trafficking remains one of the major } \\
\text { problems in the region, often closely related to } \\
\text { the problem of corruption. }\end{array}$ \\
\hline Loss of biodiversity & The social role of women has changed \\
\hline
\end{tabular}




\begin{tabular}{|l|l|}
\hline & $\begin{array}{l}\text { significantly over the last decade, especially } \\
\text { through the integration of women in the labor } \\
\text { market. }\end{array}$ \\
\cline { 1 - 1 } Groundwater contamination & $\begin{array}{l}\text { Civil security is an important issue throughout } \\
\text { the countries of the region } \\
\text { use of water }\end{array}$ \\
\cline { 1 - 1 } Air pollution & \\
\cline { 1 - 1 } Heavy metal contamination & \\
\cline { 1 - 1 } Urban waste disposal problems & \\
\cline { 1 - 1 } Information in this Table was compiled from the resource paper "Southern Agenda on \\
Trade and Environment Phase II" (Borregaard, 2003)
\end{tabular}

It is important to identify the different concerns the different stakeholders have to determine if a CSR standard can adequately address the varying concerns. However, there are some problems with properly identifying the concerns in this region. Information flows on CSR information are not as efficient as in developing countries. Not as many citizens have access to the internet to view the reports or make informed decisions. Instead, there is a reliance on NGOs to represent and fight for the concerns facing the citizens in these countries which suggest a lack of ownership of CSR initiatives at the local level (Haslam, 2004).

The next step is to determine how CSR standards address these concerns. The CSR issues identified in Figure 1 are compared to the guidelines and principles of three CSR reporting standards to determine how they are being addressed by the standard.

\section{Evaluating CSR Reporting Standards}

The three different CSR reporting standards reviewed in this article all provide valuable services to the companies that use them and the stakeholders that rely on them. They have all made a strong effort to involve a variety of stakeholders in the development of their standards. They also all provide unique services that differentiate themselves from their competition. The Global Reporting Initiative's (GRI) G3 is the most traditional form of reporting standards, comprised of numerous quantitative indicators that can be used for assessment purposes. Account Ability's AA1000 Series provides a framework for a company to involve stakeholders in the development of standards that best meet the information needs of everyone involved. The United Nations (UN) Global Compact's Communication on Progress (COP) is broader in nature, allowing corporations to choose indicators or measurements that address each principle. These organizations were selected because the Account Ability's AA1000 Series, GRI's G3, and UN Global Compact's COP represents the three most widely recognized international standards that involve external reporting on both social and environmental issues. These are the only three reporting standards listed on CorporateRegister.com, a global CSR resources website, which includes the world's largest online directory of CSR reports.

The resources available from the organizations' websites were used to evaluate the level of coverage. Heavy reliance was placed on the GRI’s “RG: Sustainability Reporting Guidelines” 
and the UN's "The Practical Guide to the United Nations Global Compact Communication on Progress (COP) - Creating, Sharing, and Posting a COP”. Table 3 provides a summary of the GRI's G3 guidelines and Table 4 lists the ten principles of the UN Global Compact's COP. The standards and guidelines of the reporting organizations were reviewed to determine the extent to which each social and environmental concern was being addressed. Then the level of coverage for each concern was ranked as high, medium, low, or none. However, this does not mean that a company issuing a COP following the ten principles of the UN's Global Compact will not contain information on wages just because wages are not specifically addressed in the ten principles. Companies are encouraged by the UN to address the ten principles in their COP and to address specific stakeholder needs. This also does not mean that a company issuing a CSR report following the GRI's G3 guidelines will definitely include information on human rights issues in foreign countries. Even though human rights issues in foreign countries are thoroughly addressed by the GRI indicators companies do not have to report on every indicator. Therefore, the rankings were determined by an overall analysis of the guidelines, principles, and indicators of the reporting organizations as they relate to the needs and concerns in the different regions of the Americas. The intention of this evaluation is to indicate, in a more systematic way for each of the reporting standards, where the relative emphasis is on addressing specific stakeholder concerns. The actual reporting of relevant information ultimately depends on the companies themselves.

Table 3. GRI-G3 reporting guidelines

Economic Performance Indicators

- Economic Performance;

- Market Presence; and

- Indirect Economic Impacts.

Aspect: Economic Performance

EC1 Direct economic value generated and distributed, including revenues, operating costs, employee compensation, donations and other community investments, retained earnings, and payments to capital providers and governments.

EC2 Financial implications and other risks and opportunities for the organization's activities due to climate change.

EC2 Financial implications and other risks and opportunities for the organization's activities due to climate change.

EC3 Coverage of the organization's defined benefit plan obligations.

EC4 Significant financial assistance received from government.

Aspect: Market Presence

EC5 Range of ratios of standard entry level wage compared to local minimum wage at significant locations of operation.

EC6 Policy, practices, and proportion of spending on locally-based suppliers at significant locations of operation.

EC7 Procedures for local hiring and proportion of senior management hired from the local community at locations of significant operation.

Aspect: Indirect Economic Impacts 
EC8 Development and impact of infrastructure investments and services provided primarily for public benefit through commercial, inkind, or pro bono engagement.

EC9 Understanding and describing significant indirect economic impacts, including the extent of impacts.

Environmental

The environmental dimension of sustainability concerns an organization's impacts on living and non-living natural systems, including ecosystems, land, air, and water. Environmental Indicators cover performance related to inputs (e.g., material, energy, water) and outputs (e.g., emissions, effluents, waste). In addition, they cover performance related to biodiversity, environmental compliance, and other relevant information such as environmental expenditure and the impacts of products and services.

Disclosure on Management Approach

Provide a concise disclosure on the Management Approach items outlined below with reference to the following Environmental Aspects:

- Materials;

- Energy;

- Water;

- Biodiversity;

- Emissions, Effluents, and Waste;

- Products and Services;

- Compliance;

- Transport; and

- Overall

Environmental Performance Indicators

Aspect: Materials

EN1 Materials used by weight or volume.

EN2 Percentage of materials used that are recycled input materials.

Aspect: Energy

EN3 Direct energy consumption by primary energy source.

EN4 Indirect energy consumption by primary source.

EN5 Energy saved due to conservation and efficiency improvements.

EN6 Initiatives to provide energy-efficient or renewable energy based products and services, and reductions in energy requirements as a result of these initiatives.

EN7 Initiatives to reduce indirect energy consumption and reductions achieved.

Aspect: Water

EN8 Total water withdrawal by source.

EN9 Water sources significantly affected by withdrawal of water.

EN10 Percentage and total volume of water recycled and reused.

Aspect: Biodiversity

EN11 Location and size of land owned, leased, managed in, or adjacent to, protected areas and areas of high biodiversity value outside protected areas.

EN12 Description of significant impacts of activities, products, and services on biodiversity in protected areas and areas of high biodiversity value outside protected areas. 


\section{Macrothink}

EN13 Habitats protected or restored.

EN14 Strategies, current actions, and future plans for managing impacts on biodiversity.

EN15 Number of IUCN Red List species and national conservation list species with habitats in areas affected by operations, by level of extinction risk.

Aspect: Emissions, Effluents, and Waste

EN16 Total direct and indirect greenhouse gas emissions by weight.

EN17 Other relevant indirect greenhouse gas emissions by weight.

EN18 Initiatives to reduce greenhouse gas emissions and reductions achieved.

EN19 Emissions of ozone-depleting substances by weight.

EN20 NO, SO, and other significant air emissions by type and weight.

EN21 Total water discharge by quality and destination.

EN22 Total weight of waste by type and disposal method.

EN23 Total number and volume of significant spills.

EN24 Weight of transported, imported, exported, or treated waste deemed hazardous under the terms of the Basel Convention Annex I, II, III, and VIII, and percentage of transported waste shipped internationally.

EN25 Identity, size, protected status, and biodiversity value of water bodies and related habitats significantly affected by the reporting organization's discharges of water and runoff.

Aspect: Products and Services

EN26 Initiatives to mitigate environmental impacts of products and services, and extent of impact mitigation.

EN27 Percentage of products sold and their packaging materials that are reclaimed by category.

Aspect : Compliance

EN28 Monetary value of significant fines and total number of non-monetary sanctions for noncompliance with environmental laws and regulations.

Aspect : Transport

EN29 Significant environmental impacts of transporting products and other goods and materials used for the organization's operations, and transporting members of the workforce.

Aspect : Overall

EN30 Total environmental protection expenditures and investments by type.

Social Performance Indicators

- Employment;

- Labor/Management Relations;

- Occupational Health and Safety;

- Training and Education; and

- Diversity and Equal Opportunity.

Labor Practices and Decent Work Performance Indicators

Aspect: Employment

LA1 Total workforce by employment type, employment contract, and region.

LA2 Total number and rate of employee turnover by age group, gender, and region.

LA3 Benefits provided to full-time employees that are not provided to temporary or part-time

employees, by major operations. 


\section{NI Macrothink}

Environmental Management and Sustainable Development

ISSN 2164-7682

2012, Vol. 1, No. 2

Aspect: Labor/Management Relations

LA4 Percentage of employees covered by collective bargaining agreements.

LA5 Minimum notice period(s) regarding operational changes, including whether it is specified in collective agreements.

Aspect: Occupational Health and Safety

LA6 Percentage of total workforce represented in formal joint management-worker health and safety committees that help monitor and advise on occupational health and safety programs.

LA7 Rates of injury, occupational diseases, lost days, and absenteeism, and number of work related fatalities by region.

LA8 Education, training, counseling, prevention, and risk-control programs in place to assist workforce members, their families, or community members regarding serious diseases.

LA9 Health and safety topics covered in formal agreements with trade unions.

Aspect: Training and Education

LA10 Average hours of training per year per employee by employee category.

LA11 Programs for skills management and lifelong learning that support the continued employability of employees and assist them in managing career endings.

LA12 Percentage of employees receiving regular performance and career development reviews.

Aspect: Diversity and Equal Opportunity

LA13 Composition of governance bodies and breakdown of employees per category according to gender, age group, minority group membership, and other indicators of diversity.

LA14 Ratio of basic salary of men to women by employee category.

Human Rights

- Investment and Procurement Practices;

- Non-discrimination;

- Freedom of Association and Collective Bargaining;

- Abolition of Child Labor;

- Prevention of Forced and Compulsory Labor;

- Complaints and Grievance Practices;

- Security Practices; and

- Indigenous Rights.

Human Rights Performance Indicators

Aspect: Investment and Procurement Practices

HR1 Percentage and total number of significant investment agreements that include human rights clauses or that have undergone human rights screening.

HR2 Percentage of significant suppliers and contractors that have undergone screening on human rights and actions taken.

HR3 Total hours of employee training on policies and procedures concerning aspects of human rights that are relevant to operations, including the percentage of employees trained.

Aspect: Non-discrimination

HR4 Total number of incidents of discrimination and actions taken.

Aspect: Freedom of Association and Collective Bargaining

HR5 Operations identified in which the right to exercise freedom of association and collective 


\section{Macrothink}

Environmental Management and Sustainable Development

ISSN 2164-7682

2012, Vol. 1, No. 2

bargaining may be at significant risk, and actions taken to support these rights.

Aspect: Child Labor

HR6 Operations identified as having significant risk for incidents of child labor, and measures taken to contribute to the elimination of child labor.

Aspect: Forced and Compulsory Labor

HR7 Operations identified as having significant risk for incidents of forced or compulsory labor, and measures to contribute to the elimination of forced or compulsory labor.

Aspect: Security Practices

HR8 Percentage of security personnel trained in the organization's policies or procedures concerning aspects of human rights that are relevant to operations.

Aspect: Indigenous Rights

HR9 Total number of incidents of violations involving rights of indigenous people and actions taken.

Society

- Community;

- Corruption;

- Public Policy;

- Anti-Competitive Behavior; and

- Compliance.

Society Performance Indicators

Aspect: Community

SO1 Nature, scope, and effectiveness of any programs and practices that assess and

manage the impacts of operations on communities, including entering, operating, and exiting.

Aspect: Corruption

SO2 Percentage and total number of business units analyzed for risks related to corruption.

SO3 Percentage of employees trained in organization's anti-corruption policies and procedures.

SO4 Actions taken in response to incidents of corruption.

Aspect : Public Policy

SO5 Public policy positions and participation in public policy development and lobbying.

SO6 Total value of financial and in-kind contributions to political parties, politicians, and related institutions by country.

Aspect: Anti-Competitive Behavior

SO7 Total number of legal actions for anticompetitive behavior, anti-trust, and monopoly practices and their outcomes.

Aspect: Compliance

SO8 Monetary value of significant fines and total number of non-monetary sanctions for noncompliance with laws and regulations.

Product Responsibility

- Customer Health and Safety;

- Product and Service Labeling;

- Marketing Communications;

- Customer Privacy; and 


\section{Macrothink}

Environmental Management and Sustainable Development

ISSN 2164-7682

2012, Vol. 1, No. 2

- Compliance.

Product Responsibility Performance Indicators

Aspect: Customer Health and Safety

PR1 Life cycle stages in which health and safety impacts of products and services are assessed for improvement, and percentage of significant products and services categories subject to such procedures.

PR2 Total number of incidents of non-compliance with regulations and voluntary codes concerning health and safety impacts of products and services during their life cycle, by type of outcomes.

Aspect : Product and Service Labeling

PR3 Type of product and service information required by procedures, and percentage of significant products and services subject to such information requirements.

PR4 Total number of incidents of non-compliance with regulations and voluntary codes concerning product and service information and labeling, by type of outcomes.

PR5 Practices related to customer satisfaction, including results of surveys measuring customer satisfaction.

Aspect : Marketing Communications

PR6 Programs for adherence to laws, standards, and voluntary codes related to marketing communications, including advertising, promotion, and sponsorship.

PR7 Total number of incidents of non-compliance with regulations and voluntary codes concerning marketing communications, including advertising, promotion, and sponsorship by type of outcomes.

Aspect : Customer Privacy

PR8 Total number of substantiated complaints regarding breaches of customer privacy and losses of customer data.

Aspect: Compliance

PR9 Monetary value of significant fines for noncompliance with laws and regulations concerning the provision and use of products and services.

Information obtained from GRI’s “RG: Sustainability Reporting Guidelines” (GRI, 2012)

Table 4. United nations global compact's ten principles

Human Rights

Principle 1: Businesses should support and respect the protection of internationally

proclaimed human rights; and

Principle 2: make sure that they are not complicit in human rights abuses.

Labour Standards

Principle 3: Businesses should uphold the freedom of association and the effective recognition of the right to collective bargaining;

Principle 4: the elimination of all forms of forced and compulsory labour;

Principle 5: the effective abolition of child labour; and

Principle 6: the elimination of discrimination in respect of employment and occupation.

Environment 
Principle 7: Businesses should support a precautionary approach to environmental challenges; Principle 8: undertake initiatives to promote greater environmental responsibility; and Principle 9: encourage the development and diffusion of environmentally friendly technologies.

Anti-Corruption

Principle 10: Businesses should work against corruption in all its forms, including extortion and bribery.

(UNGC, 2012) Obtained from unglobalcompact.org

For the AA1000 Series standards, the Accountability's Principles Standard (and formerly Framework), Assurance Standard, and Stakeholder Engagement Standard were reviewed. The AA1000 Series are comprised of principles and process standards; there are no specific stated measurable standards or indicators. Therefore, this assessment was based on how a corporation could apply the principles and not on the specific principles stated in the AA1000 Series documents. To accomplish this a sample of CSR reports was obtained that followed some or all of the AA1000 Series principles and evaluated the level of coverage, they provided to the social and environmental concerns previously identified. This was not determined to be the best option to evaluate the GRI standards or UN Global Compact's principles because a sample report may not address a specific stakeholder concern even though the reporting method may include it as an indicator. A review of the actual standards provides a more accurate evaluation. However, this would not work for the AA1000 Series Standards; therefore, reviewing actual CSR reports was determined to be the next-best option.

To select the sample reports, CorporateRegister.com was used to identify all CSR reports from American countries that were prepared using the AA1000 Series standards. Reports that also used either the GRI standards or UN Global Compact's COP were then eliminated from consideration. Since most of the reports following the AA1000 standards also used the GRI standards, only three reports in the region that met these criteria: Souza Cruz SA's 2006 report, Citizen's Bank of Canada’s 2003 report, and Imperial Tobacco Canada Ltd's 2007 report. Each of these reports was read to evaluate the coverage given to the social and environmental concerns in the region, and then ranked the level of coverage appropriately (None, Low, Medium, or High coverage). Table 5 provides a summary of how well each of these standards addresses the specific social and environmental needs and concerns of the three regions in North and South America.

Table 5. How CSR reporting standards address stakeholder needs and concerns

\begin{tabular}{|l|c|c|c|}
\hline & \multicolumn{3}{|c|}{ Level of Coverage by Reporting Standards } \\
\hline Social and & GRI G3 & AA1000 Series & UN Global \\
Environmental & Relevant & Relevant Standards & Compact \\
Concerns by Region & Indicators & & Relevant \\
& & & Principles \\
\hline
\end{tabular}




\begin{tabular}{|c|c|c|c|c|c|}
\hline$\frac{\text { Non-Latin American }}{\underline{\text { Countries }}}$ & & $\begin{array}{l}\text { Citizen’s } \\
\text { Bank } \\
\text { AA1000 } \\
\text { Assurance } \\
\text { standard }\end{array}$ & $\begin{array}{c}\text { Souza Cruz } \\
\text { AA1000 } \\
\text { Framework } \\
\text { standard }\end{array}$ & $\begin{array}{l}\text { Imperial } \\
\text { Tobacco } \\
\text { Canada } \\
\text { Ltd. } \\
\text { AA1000 } \\
\text { Series } \\
\text { framework }\end{array}$ & \\
\hline \multirow[t]{2}{*}{$\begin{array}{l}\text { 1. Employment/ } \\
\text { Competition }\end{array}$} & \begin{tabular}{l}
\multicolumn{1}{c}{ Medium } \\
Employment \\
indicators are \\
provided in Org. \\
Profile 3.8,2.9, \\
EC7, LA1, and \\
SO5. Issues of \\
competition and \\
economic
\end{tabular} & \multicolumn{3}{|c|}{$\begin{array}{l}\text { Only the report by Citizen’s Bank had } \\
\text { thorough coverage of employment } \\
\text { issues, including employee composition } \\
\text { by gender, ethnicity, and those with } \\
\text { disabilities. They also provided detail on } \\
\text { labor relations and employee } \\
\text { engagement. }\end{array}$} & \multirow[t]{2}{*}{ None } \\
\hline & $\begin{array}{l}\text { be included in the } \\
\text { Org. Profile, but } \\
\text { this is not } \\
\text { specifically } \\
\text { mentioned. }\end{array}$ & pp. $19-20$ & pp. 47-49 & pp. 25-26 & \\
\hline \multirow[t]{2}{*}{ 2. Wages } & \begin{tabular}{l}
\multicolumn{1}{c}{ High } \\
See the following \\
indicators: \\
EC1,EC3,EC5
\end{tabular} & \multicolumn{3}{|c|}{$\begin{array}{c}\text { Low } \\
\text { (Medium, None, None respectively) }\end{array}$} & \multirow[t]{2}{*}{ None } \\
\hline & & $\begin{array}{l}\text { pp. 6, } \\
19-20\end{array}$ & None & None & \\
\hline \multirow[t]{2}{*}{$\begin{array}{l}\text { 3. Environmental } \\
\text { impact }\end{array}$} & \begin{tabular}{l}
\multicolumn{1}{c}{ High } \\
See the following \\
indicators: \\
EN1-EN29
\end{tabular} & \multicolumn{3}{|c|}{$\begin{array}{l}\text { The Citizen's Bank report included a } \\
\text { detailed analysis on their energy use, } \\
\text { waste management, and overall } \\
\text { environmental performance. Souza Cruz } \\
\text { listed the environmental campaigns and } \\
\text { initiatives of the company. }\end{array}$} & $\begin{array}{l}\quad \text { Medium } \\
\text { Principles 7,8,9 } \\
\text { encourage } \\
\text { environmentally } \\
\text { responsible } \\
\text { actions, } \\
\text { however there } \\
\text { are no }\end{array}$ \\
\hline & & pp. 6, & pp.12,21,27,46 & None & encourage the \\
\hline
\end{tabular}




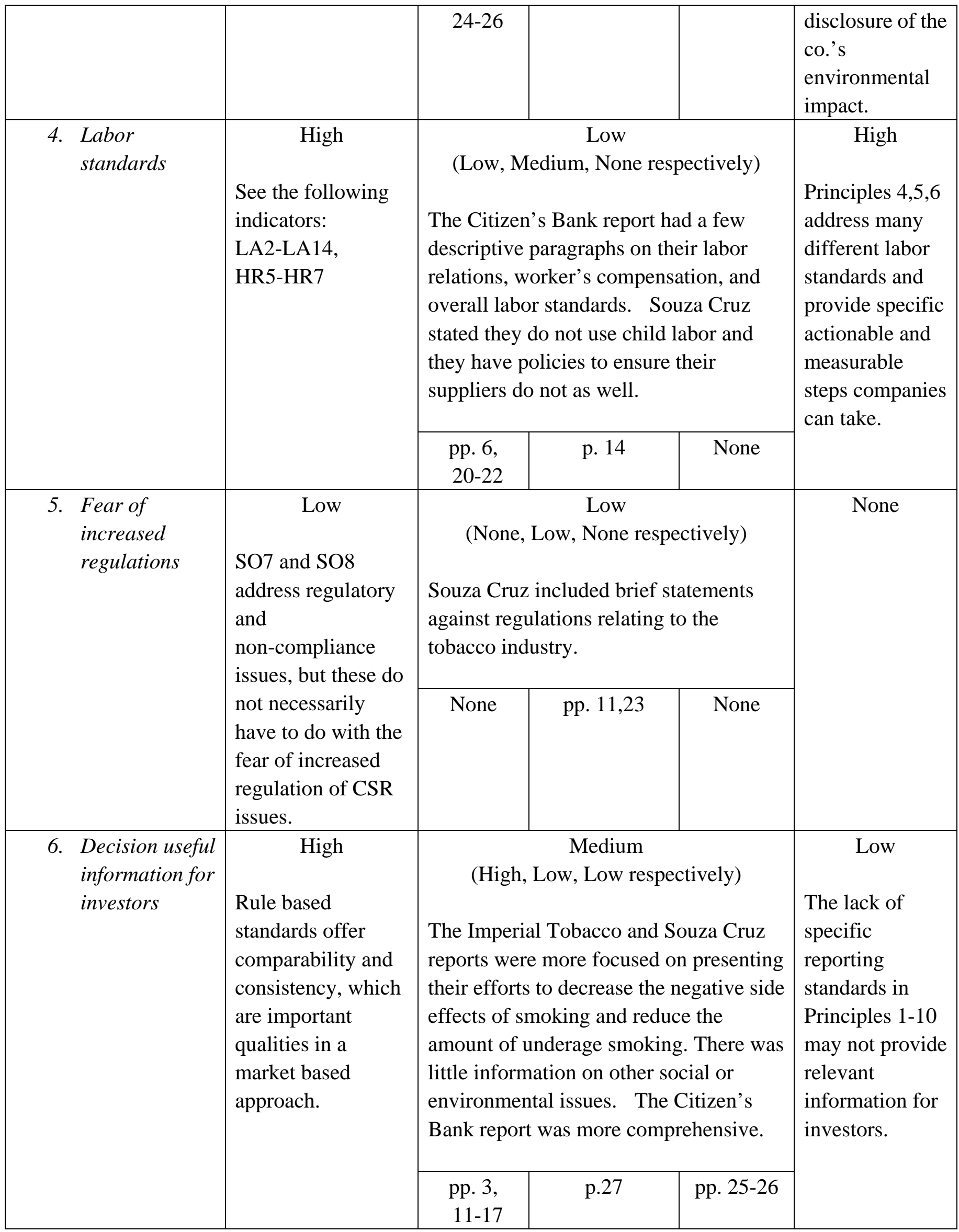




\begin{tabular}{|c|c|c|c|c|c|}
\hline \multirow[t]{2}{*}{$\begin{array}{l}\text { 7. Human Rights } \\
\text { issues in } \\
\text { foreign } \\
\text { countries }\end{array}$} & \multirow{2}{*}{$\begin{array}{l}\text { High } \\
\text { See the following } \\
\text { indicators: } \\
\text { HR1-HR9, } \\
\text { LA6-LA9, and PR } \\
\text { 1,2,8 }\end{array}$} & \multicolumn{3}{|c|}{$\begin{array}{l}\text { Low } \\
\text { (Low, None, Low respectively) } \\
\text { The Imperial Tobacco and Citizen’s } \\
\text { Bank reports each addressed this briefly. }\end{array}$} & \multirow{2}{*}{\begin{tabular}{l}
\multicolumn{1}{|c}{ Medium } \\
Principles 1,2 of \\
the Global \\
Compact \\
address issues \\
of human rights, \\
however not to \\
the same degree \\
of specificity as \\
they do labor \\
standards. \\
This may leave \\
too much \\
interpretation to \\
the reporting \\
companies.
\end{tabular}} \\
\hline & & pp. 6,19 & None & p. 2 & \\
\hline \multicolumn{6}{|l|}{$\begin{array}{c}\text { Large Latin } \\
\text { American Countries }\end{array}$} \\
\hline \multirow[t]{2}{*}{$\begin{array}{l}\text { 1. Employment/ } \\
\text { Competition }\end{array}$} & \multirow{2}{*}{$\begin{array}{l}\quad \text { Medium } \\
\text { Employment } \\
\text { indicators are } \\
\text { provided in Org. } \\
\text { Profile 3.8,2.9, } \\
\text { EC7, LA1, and } \\
\text { SO5. Issues of } \\
\text { competition and } \\
\text { economic } \\
\text { sustainability can } \\
\text { be included in the } \\
\text { Org. Profile, but } \\
\text { this is not } \\
\text { specifically } \\
\text { mentioned. }\end{array}$} & \multicolumn{3}{|c|}{$\begin{array}{l}\text { Medium } \\
\text { (High, Medium, Low respectively) } \\
\text { Only the report by Citizen’s Bank had } \\
\text { thorough coverage of employment } \\
\text { issues, including employee composition } \\
\text { by gender, ethnicity, and those with } \\
\text { disabilities. They also provided detail } \\
\text { on labor relations and employee } \\
\text { engagement. }\end{array}$} & \multirow[t]{2}{*}{ None } \\
\hline & & pp. $19-20$ & pp. 47-49 & pp. 25-26 & \\
\hline 2. Wages & $\begin{array}{l}\quad \text { High } \\
\text { See the following } \\
\text { indicators: } \\
\text { EC1,EC3,EC5 }\end{array}$ & \multicolumn{3}{|c|}{$\begin{array}{l}\text { Low } \\
\text { (Medium, None, None respectively) } \\
\text { The Citizen’s Bank report included a } \\
\text { description of their compensation plan } \\
\text { and compared their base pay to the } \\
\text { industry average. }\end{array}$} & None \\
\hline
\end{tabular}




\begin{tabular}{|c|c|c|c|c|c|}
\hline & & $\begin{array}{l}\text { pp. 6, } \\
19-20\end{array}$ & None & None & \\
\hline \multirow[t]{2}{*}{ 3. Poverty } & \multirow{2}{*}{\begin{tabular}{l}
\multicolumn{1}{c}{ Medium } \\
Community \\
involvement and \\
impact are included \\
in EC1, EC8, and \\
EC9, but regional \\
and national \\
indicators relating \\
to poverty are not \\
provided.
\end{tabular}} & \multicolumn{3}{|c|}{$\begin{array}{l}\text { Citizen’s Bank and Souza Cruz both list } \\
\text { their donations, many of which address } \\
\text { issues relating to poverty. }\end{array}$} & $\begin{array}{l}\text { Low } \\
\text { Aside from the } \\
\text { general mention } \\
\text { of protecting } \\
\text { human rights in } \\
\text { Principle } 1 \text {. }\end{array}$ \\
\hline & & pp. 28-30 & pp. 15,59 & None & $\begin{array}{l}\text { issues of wages, } \\
\text { employment, } \\
\text { and poverty are } \\
\text { not mentioned. }\end{array}$ \\
\hline \multirow[t]{2}{*}{$\begin{array}{l}\text { 4. Fear of } \\
\text { increased } \\
\text { regulations }\end{array}$} & \multirow{2}{*}{$\begin{array}{l}\quad \text { Low } \\
\text { SO7 and SO8 } \\
\text { address regulatory } \\
\text { and } \\
\text { non-compliance } \\
\text { issues, but these do } \\
\text { not necessarily } \\
\text { have to do with the } \\
\text { fear of increased } \\
\text { regulation of CSR } \\
\text { issues. }\end{array}$} & \multicolumn{3}{|c|}{$\begin{array}{c}\text { Low } \\
\text { (None, Low, None respectively) }\end{array}$} & \multirow[t]{2}{*}{ None } \\
\hline & & None & pp. 11,23 & None & \\
\hline \multirow[t]{2}{*}{$\begin{array}{l}\text { 5. Labor } \\
\text { standards }\end{array}$} & \multirow[t]{2}{*}{$\begin{array}{l}\text { See the following } \\
\text { indicators: } \\
\text { LA2-LA14, } \\
\text { HR5-HR7 }\end{array}$} & \multicolumn{3}{|c|}{$\begin{array}{l}\text { The Citizen's Bank report had a few } \\
\text { descriptive paragraphs on their labor } \\
\text { relations, worker's compensation, and } \\
\text { overall labor standards. Souza Cruz } \\
\text { stated they do not use child labor and } \\
\text { they have policies to ensure their } \\
\text { suppliers do not as well. }\end{array}$} & \multirow[t]{2}{*}{\begin{tabular}{l}
\multicolumn{1}{c}{ Medium } \\
Principles 4,5,6 \\
address many \\
different labor \\
standards and \\
provide specific \\
actionable and \\
measurable \\
steps companies \\
can take.
\end{tabular}} \\
\hline & & $\begin{array}{l}\text { pp. 6, } \\
20-22 \\
\end{array}$ & p. 14 & None & \\
\hline $\begin{array}{l}\text { 6. Decision useful } \\
\text { information for } \\
\text { supply chain }\end{array}$ & $\begin{array}{c}\text { High } \\
\text { See the following }\end{array}$ & (High, & $\begin{array}{l}\text { High } \\
\text { gh, High re }\end{array}$ & jely) & $\begin{array}{l}\text { Medium } \\
\text { The lack of }\end{array}$ \\
\hline
\end{tabular}




\begin{tabular}{|c|c|c|c|c|c|}
\hline \multirow[t]{2}{*}{ and community } & \multirow[t]{2}{*}{$\begin{array}{l}\text { indicators: EC6, } \\
\text { HR2, PR1-PR9. }\end{array}$} & \multicolumn{3}{|c|}{$\begin{array}{l}\text { The Citizen’s Bank report was the most } \\
\text { comprehensive report in addressing a } \\
\text { variety of social and environmental } \\
\text { issues through the use of quantitative } \\
\text { indicators. The Imperial Tobacco and } \\
\text { Souza Cruz reports were developed to } \\
\text { address the specific concerns that } \\
\text { stakeholders had with the tobacco } \\
\text { industry. }\end{array}$} & \multirow{2}{*}{$\begin{array}{l}\text { specific } \\
\text { reporting } \\
\text { standards in } \\
\text { Principles 1-10 } \\
\text { may not provide } \\
\text { decision useful } \\
\text { information to } \\
\text { all stakeholders. } \\
\text { Although } \\
\text { encouraged by } \\
\text { the Global } \\
\text { Compact, } \\
\text { stakeholder } \\
\text { engagement } \\
\text { does is not } \\
\text { given the same } \\
\text { priority as it has } \\
\text { from the other } \\
\text { two standards. }\end{array}$} \\
\hline & & $\begin{array}{l}\text { pp. 3, } \\
11-17\end{array}$ & $\begin{array}{l}\text { pp.14-19, } \\
28,47\end{array}$ & $\begin{array}{l}\text { pp.18-19, } \\
25-26\end{array}$ & \\
\hline \multirow[t]{2}{*}{$\begin{array}{l}\text { 7. Environmental } \\
\text { impact }\end{array}$} & \multirow[t]{2}{*}{\begin{tabular}{l}
\multicolumn{1}{c}{ High } \\
See the following \\
indicators: \\
EN1-EN29
\end{tabular}} & \multicolumn{3}{|c|}{$\begin{array}{l}\text { Medium } \\
\text { (High, Medium, None respectively) } \\
\text { The Citizen’s Bank report included a } \\
\text { detailed analysis on their energy use, } \\
\text { waste management, and overall } \\
\text { environmental performance. Souza } \\
\text { Cruz listed the environmental campaigns } \\
\text { and initiatives of the company. }\end{array}$} & \multirow{2}{*}{\begin{tabular}{l}
\multicolumn{1}{c}{ Medium } \\
Principles 7,8,9 \\
encourage \\
environmentally \\
responsible \\
actions, \\
however there \\
are no \\
principles that \\
encourage the \\
disclosure of the \\
co.'s \\
environmental \\
impact. \\
\end{tabular}} \\
\hline & & $\begin{array}{l}\text { pp. 6, } \\
24-26\end{array}$ & pp.12,21,27,46 & None & \\
\hline \multicolumn{6}{|l|}{$\begin{array}{c}\text { Small Latin } \\
\text { American Countries }\end{array}$} \\
\hline $\begin{array}{l}\text { 1. Employment/ } \\
\text { Competition }\end{array}$ & $\begin{array}{l}\quad \text { Medium } \\
\text { Employment } \\
\text { indicators are } \\
\text { provided in Org. } \\
\text { Profile 3.8,2.9, }\end{array}$ & \multicolumn{3}{|c|}{$\begin{array}{l}\text { Medium } \\
\text { (High, Medium, Low respectively) } \\
\text { Only the report by Citizen's Bank had } \\
\text { thorough coverage of employment } \\
\text { issues, including employee composition }\end{array}$} & None \\
\hline
\end{tabular}




\begin{tabular}{|c|c|c|c|c|c|}
\hline & $\begin{array}{l}\text { EC7, LA1, and } \\
\text { SO5. Issues of } \\
\text { competition and } \\
\text { economic }\end{array}$ & \multicolumn{3}{|c|}{$\begin{array}{l}\text { by gender, ethnicity, and those with } \\
\text { disabilities. They also provided detail } \\
\text { on labor relations and employee } \\
\text { engagement. }\end{array}$} & \\
\hline & $\begin{array}{l}\text { be included in the } \\
\text { Org. Profile, but } \\
\text { this is not } \\
\text { specifically } \\
\text { mentioned. }\end{array}$ & pp. 19-20 & pp. 47-4 & pp. 25-26 & \\
\hline \multirow[t]{2}{*}{ 2. Poverty } & \begin{tabular}{l}
\multicolumn{1}{c}{ Medium } \\
Community \\
involvement and \\
impact are included \\
in EC1, EC8, and \\
EC9 but regional
\end{tabular} & \multicolumn{3}{|c|}{$\begin{array}{l}\text { Citizen’s Bank and Souza Cruz both list } \\
\text { their donations, many of which address } \\
\text { issues relating to poverty. }\end{array}$} & $\begin{array}{l}\text { Low } \\
\text { Aside from the } \\
\text { general mention } \\
\text { of protecting } \\
\text { human rights in } \\
\text { Princinle } 1\end{array}$ \\
\hline & $\begin{array}{l}\text { and national } \\
\text { indicators relating } \\
\text { to poverty are not } \\
\text { provided. }\end{array}$ & pp. 28-30 & pp. 15,5 & None & $\begin{array}{l}\text { issues of wages, } \\
\text { employment, } \\
\text { and poverty are } \\
\text { not mentioned. }\end{array}$ \\
\hline \multirow[t]{2}{*}{$\begin{array}{l}\text { 3. Exploitation } \\
\text { from } \\
\text { Developed } \\
\text { countries }\end{array}$} & $\begin{array}{l}\text { Low } \\
\text { This can be } \\
\text { included in the Org. } \\
\text { Profile } 2.8 \text { and } 2.9 \\
\text { or interpreted from } \\
\text { the various social } \\
\text { and environmental } \\
\text { indicators, but there } \\
\text { are no specific } \\
\text { indicators that } \\
\text { address }\end{array}$ & \multicolumn{3}{|c|}{$\begin{array}{l}\text { The Imperial Tobacco and Souza Cruz } \\
\text { reports were more focused on presenting } \\
\text { their efforts to decrease the negative side } \\
\text { effects of smoking and reduce the } \\
\text { amount of underage smoking. Souza } \\
\text { Cruz has a detailed description of their } \\
\text { "It's Here" campaign to help discourage } \\
\text { the sale of cigarettes to minors. }\end{array}$} & \begin{tabular}{l}
\multicolumn{1}{c}{ Low } \\
There are not \\
specific \\
reporting \\
criteria that \\
address this \\
concern, \\
although \\
Principle 5 can \\
be tied to \\
exploitation.
\end{tabular} \\
\hline & exploitation. & p. 6 & p.14 & pp. 20-21 & \\
\hline \multirow[t]{2}{*}{ 4. Wages } & $\begin{array}{l}\quad \text { High } \\
\text { See the following } \\
\text { indicators: } \\
\text { EC1,EC3,EC5 }\end{array}$ & \multicolumn{3}{|c|}{$\begin{array}{l}\text { The Citizen's Bank report included a } \\
\text { description of their compensation plan } \\
\text { and compared their base pay to the } \\
\text { industry average. }\end{array}$} & None \\
\hline & & pp. 6, & None & None & \\
\hline
\end{tabular}




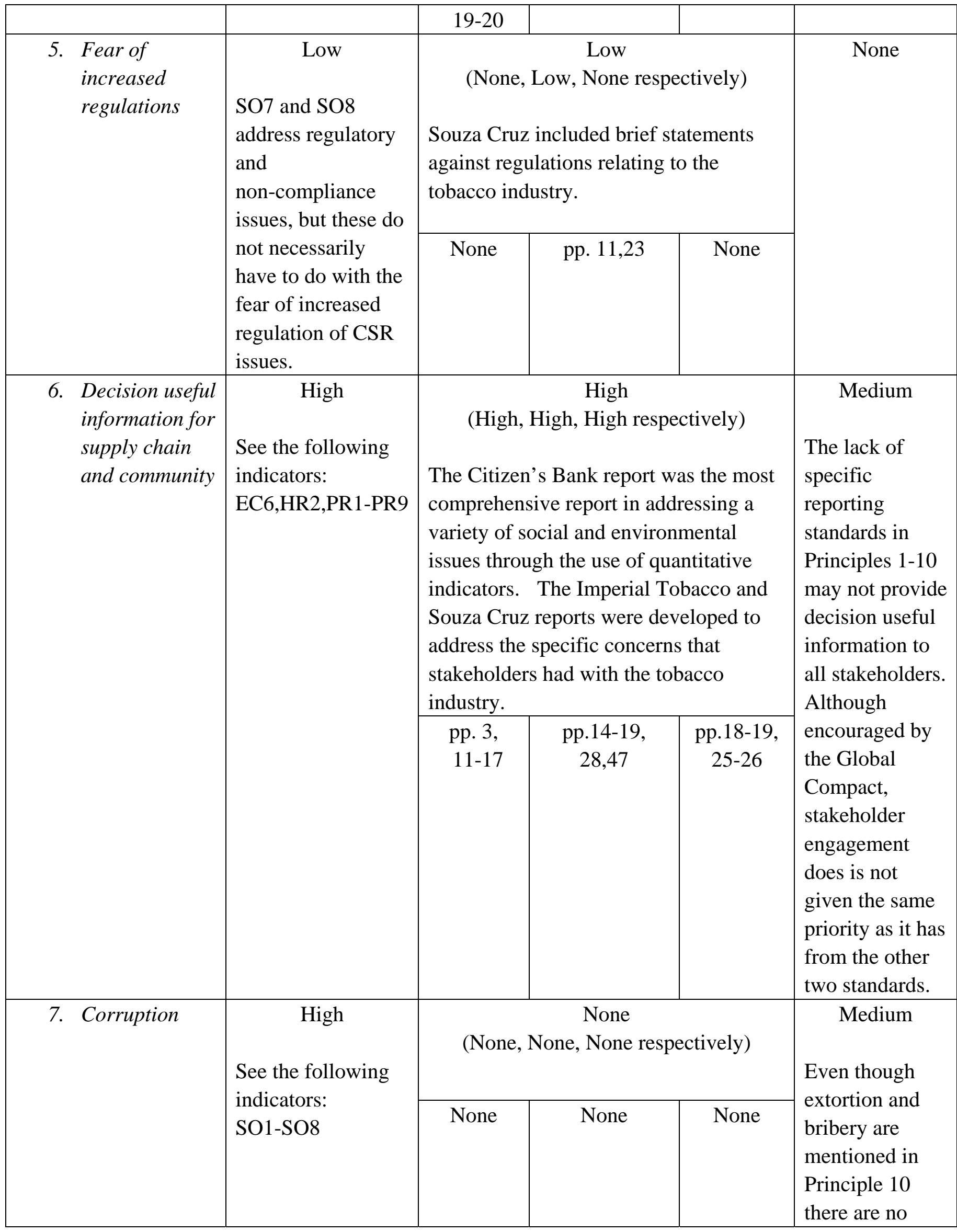




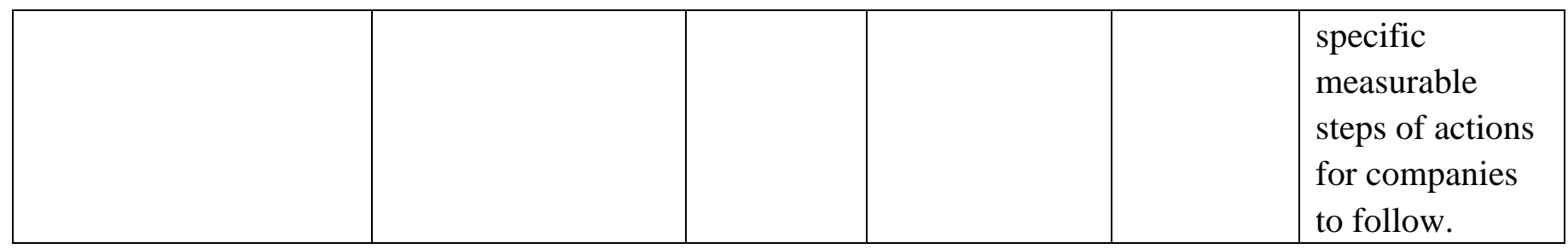

\section{Conclusion}

There were limitations to this analysis. The ranking of coverage for each issue was subjective. This author was the only person to evaluate and rank the level of coverage. In addition, the sample of AA1000 reports, although complete, was small and dated. The AA1000 is used more extensively in Europe. However, as a principle based standard, the methodology used in this article is still deemed appropriate based on the intended goals. Additional research opportunities exist to use additional regions of the World to compare the content of more CSR reports that solely relied on AA1000 standards.

Aside from the aforementioned limitations, Table 5 does provide useful information as to the potential each of these three standards has towards adequately addressing stakeholders' needs. Because of the comprehensive nature of the GRI's G3, these standards offered the most coverage, although not every need was addressed. The AA1000 reports provided evidence as to what many view is the main problem with the use of voluntary CSR reporting, and that is the lack of decision useful information. The Imperial Tobacco Canada Ltd.'s report read more like an anti-tobacco brochure. Rather than addressing a variety of stakeholder issues, this report focused on what the company is doing to inform the public on the dangers and risks of tobacco use. While some may see the benefit of such information, a CSR report such as this does little to promote CSR reporting as a comprehensive market-based instrument. This report only provides useful information to a limited group of stakeholders.

The UN Global Compact addresses a wider variety of issues, but its lack of specific reporting requirements could yield inadequate coverage of stakeholders' needs. The analysis in Table 5 details how the different reporting standards met the stakeholder needs in the different regions of the Americas provided additional evidence that the GRI standards provided the most thorough coverage. However, even these standards failed to adequately report on some of the most controversial stakeholder needs in the region, such as job creation, competition, and employment. As a voluntary mechanism it would be unlikely that a company would report negative information or forecasts on potential future job cuts, outsourcing, or relocation plans. Therefore, some key issues are still not being adequately reported if companies are following these standards.

This analysis reinforces recent events in the transformation of CSR reporting standards. Each of these three CSR reporting organizations takes great efforts to include a variety of stakeholders in the development of their standards. However, each organization has a slightly different agenda. Even with the development of a new Principles Standard in 2008, the AA1000 Series has concentrated more in recent years on the assurance and stakeholder engagement functions. The AA1000 Series standards are promoted by Accountability as 
being a supporting resource for companies issuing GRI reports. The UN Global Compact has also recognized the stature of the GRI and even recommends using the G3 standards to address their ten principles. In addition, these events have taken the GRI a few steps closer towards achieving their mission of becoming the globally accepted agreed upon CSR reporting standard. The growth and development of CSR reporting standards are still in its infancy. As these standards continue to evolve, they will likely provide higher levels of decision useful information.

\section{References}

Account Ability. (2012). Account Ability website, http://www.accountability.org/, accessed April 20, 2012.

Araya, M. (2006). Exploring terra incognita: Non-financial reporting in corporate Latin America.

The Journal of Corporate Citizenship, 21. http://search.proquest.com.ezproxy.saintleo.edu/docview/211964155?accountid=4870.

Borregaard, N. (2003). Southern Agenda on Trade and Environment Phase II, South America. Resource Paper, International Institute for Sustainable Development. http://www.iisd.org/pdf/2006/trade_sate_phase2.pdf.

GRI. (2012). Global Reporting Initiative. www.globalreporting.org, accessed April 21, 2012.

Haslam, P. A. (2004). The corporate social responsibility system in Latin America and the Caribbean.Policy Paper. Canadian Foundation for the Americas, http://www.focal.ca/pdf/csr_04.pdf.

IMF. (2012). International Monetary Fund. www.imfstatistics.org/bop accessed June 13, 2012.

KPMG. (2008). KPMG International Survey of Corporate Responsibility Reporting 2008. Research conducted by University of Amsterdam and KPMG Global Sustainability Services. http://www.kpmg.com/EU/en/Documents/KPMG_International_survey_Corporate_responsib ility_Survey_Reporting_2008.pdf.

KPMG. (2011). KPMG International Survey of Corporate Responsibility Reporting 2011. Research conducted by KPMG Global Sustainability Services. http://www.kpmg.com/Global/en/IssuesAndInsights/ArticlesPublications/corporate-responsib ility/Documents/2011-survey.pdf.

Marlin, J. T. \& Marlin, A. (2003). A brief history of social reporting. Business Respect. 51.http://www.mallenbaker.net/csr/page.php?Story_ID=857.

Sanchez, M. (2005). Latin America's income disparity huge. Seattle Post-Intelligencer. July 8. http://search.proquest.com.ezproxy.saintleo.edu/docview/385519546?accountid=4870.

UNGC. (2012). United Nations Global Compact. www.unglobalcompact.org, accessed April 21, 2012. 


\section{Macrothink}

Environmental Management and Sustainable Development

ISSN 2164-7682 2012, Vol. 1, No. 2

Vives, A. \& Peinado-Vara, E. (2004). Corporate responsibility: Deeds not words. II Inter-American Conference on Corporate Social Responsibility Proceedings. http://www.iadb.org/mif/csramericas/2004/sections/publications.asp.

\section{Copyright Disclaimer}

Copyright reserved by the author(s).

This article is an open-access article distributed under the terms and conditions of the Creative Commons Attribution license (http://creativecommons.org/licenses/by/3.0/). 